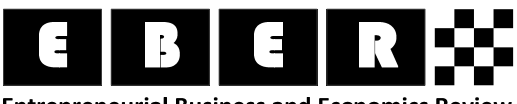

Entrepreneurial Business and Economics Review

2014, Vol. 2, No. 3

\title{
Editorial: FDI in Central Europe
}

Literature offers numerous concepts, models, and theories explaining foreign direct investment (FDI) inflows and outflows. The most popular classification of these theories divides them into three groups (Kilic et al., 2014): macro-level theories, micro-level theories, and development theories, which combine elements of both macro- and microlevel theories (Wach \& Wojciechowski, 2014; Wojciechowski, 2013).

Macro-level FDI theories include capital market theory, dynamic macroeconomic theory, exchange rate theory, economic geography, gravity approach, and institutional analysis, among others. Macroeconomic theories treat FDI as a form of capital flow between different economies in the world, attempting to explain the motivations behind, and determinants of, FDI. Micro-level FDI theories include firm specific advantage theory, oligopolistic markets theory, the theory of internalisation, and eclectic theory, among others. Microeconomic theories are elaborated from the point of view of multinational companies. These theories try to explain why multinational companies choose FDI rather than other entry modes like exporting or licensing. Development theories of FDI (mixed theories) include product life cycle theory, Japanese FDI theories, and five stage theory, among others. Recently, different theories of behavioural economics have emerged in the economic theory of FDI, including network approach (Hosseini, 2005). New perspectives on FDI include the dynamic capabilities perspective, the evolutionary perspective with its core Scandinavian model (U-model), and the integration-responsiveness perspective called the I-R paradigm (Prahalad \& Doz, 1987).

Based on the above-mentioned approaches and concepts, numerous studies have been conducted around the globe. In the previous issues, the research field of FDI appeared in almost each issue (Wojciechowski, 2013; Owczarczuk, 2013; Patnaik, 2013), thus, we decided to dedicate an entire issue to this very crucial topic for the economy, including, of course, all economies of Central and Eastern European countries. Various authors have empirically proven that membership in the EMU and the EU, taxation differences, and common borders have a significant influence on the stock FDI concentration in certain cases. Investment motives among the V4, as well as the size and dynamics of outward FDI, have undergone significant changes in the last decade (Wach \& Wojciechowski, 2014; Marona \& Bieniek, 2013).This issue presents six papers, including five studies dedicated to the region of Central Europe, especially the Visegrad Group.

Wojciech Zysk and Sławomir Śmiech from Cracow University of Economics (Poland) try to empirically verify the influence of FDI on foreign trade in all four Visegrad countries. 
Jacek Klich, also from Cracow University of Economics (Poland), tries to answer the question of whether the Visegrad countries' membership in the European Union has changed something in terms of FDI inflow into the Visegrad countries after 2004.

Magdalena Rudnicka from Wrocław University of Economics (Poland) elaborates on the characteristics of service offshoring in Central and Eastern European countries with special attention to the V4.

Magdolna Sass and Andrea Éltető, both from the Hungarian Academy of Sciences (Hungary), as well as Katalin Antalóczy from Budapest Business School (Hungary), analyse outward FDI from Hungary and discuss the emergence of Hungarian multinationals using a case study method.

Robert Marciniak from the University of Miskolc (Hungary) presents an interesting outlook on global shared service trends in the markets of Central and Eastern European countries (CEEs).

Last but not least, Adam Marszk from Gdańsk University of Technology (Poland) presents a very brief, but interesting overview of the main theoretical concepts linking economic integration and foreign direct investment.

\section{Krzysztof Wach \\ Editor-in-Chief}

\section{REFERENCES}

Hosseini, H. (2005). An economic theory of FDI: a behavioural economic and historical approach. The Journal of Socio-Economics, 34(4), 528-541.

Kilic, C., Bayar, Y., \& Arica, F. (2014). Effects of currency unions on foreign direct investment inflows: the European economic and monetary union case. International Journal of Economics and Financial Issues, 4(1), 8-15.

Marona, B., \& Bieniek, A. (2013). Wykorzystanie modelu VECM do analizy wpływu bezpośrednich inwestycji zagranicznych na gospodarkę Polski w latach 1996-2010. Acta Universitatis Nicolai Copernici - Ekonomia, XLIV(2), 1-14.

Owczarczuk, M. (2013). Government incentives and FDI into R\&D - The case of Visegrad countries. Entrepreneurial Business and Economics Review, 1(2), 73-86.

Patnaik, O. (2013). Business opportunities in India for Polish entrepreneurs. Entrepreneurial Business and Economics Review, 1(3), 71-85.

Prahalad, C.K., \& Doz, Y. (1987). The Multinational Mission: Balancing Local Demands and Global Vision, New York, NY: The Free Press.

Wach, K., \& Wojciechowski, L. (2014). The Determinants of Outwards Foreign Direct Investment from the V4 Countries: Importance of EU and MU Membership - A Panel Gravity Model Approach. In: J. Suchecka, \& P. Strożek (Eds.), Spatial Econometrics and Regional Economic Analysis. Proceedings of the 3 Scientific Conference. Łódź, 9-10 June 2014. University Łódź.

Wojciechowski, L. (2013). The Determinants of FDI Flows from the EU-15 to the Visegrad Group Countries - A Panel Gravity Model Approach. Entrepreneurial Business and Economics Review, 1(1), 7-22. 